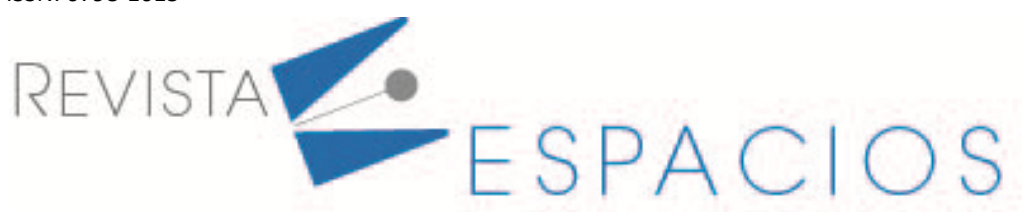

\title{
Study of biogas generation from guinea pig excretions in discontinuous and Taiwanese biodigesters at elevations above 2,500 masl
}

\section{Estudio de la generación de biogás a partir de excreciones de cobayas en biodigestores discontinuos y taiwaneses a elevaciones superiores a $2.500 \mathrm{msnm}$}

\author{
ARROYO, Flavio R. ${ }^{1}$ \\ MONTA, Luis G. ${ }^{2}$ \\ REMACHE, Abel P. ${ }^{3}$ \\ TIPAN, Juan G. ${ }^{4}$
}

\begin{abstract}
The study was carried out to find out if it is feasible to use guinea pig excretions for the generation of biogas as an alternative energy source at altitudes above 2,500 meters above sea level. Two types of biodigesters were investigated, one discontinuous and the other Taiwanese. The biogas was subjected to a gas chromatography analysis, which showed the concentration in weight and moles of $\mathrm{CO}_{2}$, methane, nitrogen and water, relative density, molecular weight and caloric value. The gas from the discontinuous biodigester was the one with the best results, since its composition had $50.10 \%$ mol of methane.

Keywords: biodigesters, biogas, taiwanese biodigester, discontinuous biodigester.

\section{Resumen}

El estudio se realizó para averiguar si es factible utilizar excreciones de cuy para la generación de biogás como fuente de energía alternativa en altitudes superiores a los 2.500 metros sobre el nivel del mar. Se investigaron dos tipos de biodigestores, uno discontinuo y otro taiwanés. El biogás se sometió a un análisis de cromatografía de gases, que mostró la concentración en peso y moles de $\mathrm{CO}_{2}$, metano, nitrógeno y agua, densidad relativa, peso molecular y valor calórico. El gas del biodigestor discontinuo fue el de mejores resultados, ya que su composición tenía $50,10 \%$ mol de metano.

Palabras Clave: biodigestores, biogás, biodigestor taiwanés, biodigestor discontinuo.
\end{abstract}

\section{Introduction}

The need to use alternative energies has gained greater emphasis around the world in recent years. The reason for taking into account this type of energy is due to the problem of global warming that has generated dramatic

\footnotetext{
${ }^{1}$ Faculty of Engineering, Physical Sciences and Mathematics, Central University of Ecuador, University of Valladolid Spain. Contact email: frarroyo@uce.edu.ec

${ }^{2}$ Faculty of Automotive Engineering, UIDE, Ecuador. Contact e-mail: , luvak_gus@hotmail.com

${ }^{3}$ Faculty of Engineering, Physical Sciences and Mathematics, Central University of Ecuador. Contact e-mail: apremache@uce.edu.ec

${ }^{4}$ Faculty of Automotive Engineering, UIDE, Ecuador. Contact e-mail: gabri_tt07@hotmail.com
} 
changes in the climate affecting millions of people. One of the main elements that has contributed to this situation is, to a large extent, the use of fossil fuels. The residues of these fuels are very polluting gases, that is why energy sources friendly to the environment have been sought; also, they should be inexhaustible to assure their long-term use.

Among these alternatives there is the generation of biogas, which will be the focus of this study. Biogas can be generated from waste of organic origin, which is of great help to mitigate the harmful effects of garbage decomposition in the open air.

Farm waste, especially waste generated by the animals, is the main source for feeding biodigesters that generate biogas. This is a source of energy friendly to the environment, which is why this way of obtaining a non-fossil fuel has been taken into account. Guinea-pig raising is a deeply rooted activity in Ecuador, especially in the rural areas of the Sierra. Generally, non-technical systems are used, and guinea-pig excretions (feces) are simply used as fertilizer for the fields.

With this background, it is desired to use this organic waste as raw material for the generation of biogas and in this way encourage the use of all available resources. It is sought to generate a source of renewable energy that would have a favorable impact on the environment, because with the creation of a biodigester, a non-fossil fuel source would be found and at the same time a fertilizer would be obtained, that can be used for the treatment of soils.

In distant and remote locations, where there are often no necessary basic services, this system of biogas generation can be very useful, since it would serve as a source of replacement for the traditional wood stove. An additional advantage is that in these places the raising of guinea pig is very widespread, so the raw material for the functioning of the biodigester would be guaranteed and accessible.

Depending on the requirements, the remains of the organic waste once the anaerobic digestion process is completed can also be used as fertilizer, having two great benefits that make the generation of biogas viable to be studied, analyzed and implemented to take advantage of the waste generated as a form of clean energy.

Biogas"... is a combustible gas a little lighter than air (density $0.94 \mathrm{Kg} / \mathrm{m}^{3}$ at atmospheric conditions), it has an ignition temperature of around $700{ }^{\circ} \mathrm{C}$ and the flame temperature reaches $870{ }^{\circ} \mathrm{C}$ " (López, 2011).

Fernández Salgado (2009) states that "The composition of the gas is variable, but it is mainly composed of methane (55-65 \%) and $\mathrm{CO}_{2}$ (35-45 \%); and, to a lesser extent, by nitrogen (0-3 \%), hydrogen (0-1 \%), oxygen (0$1 \%)$ and hydrogen sulfide (traces)".

Rosas (2007) points out that biogas presents a blue flame at the moment it is burned, this makes it very little noticeable in daylight. Another relevant information is its calorific value, which close to $5,342 \mathrm{kcal} / \mathrm{m}^{3}$, below the values of gases such as butane $\left(22,000 \mathrm{kcal} / \mathrm{m}^{3}\right)$ and propane $\left(28000 \mathrm{kcal} / \mathrm{m}^{3}\right)$.

The so-called biogas is produced from the anaerobic decomposition of buried domestic garbage and animal manure. The urban solid waste (USW) are also raw material to feed the reactors that generate biogas (González, 2009). In the process of obtaining biogas, many pathogenic bacteria are eliminated and controlled, including the reduction of the volume of waste (López, 2011).

There are factors that can affect the digestion process, such as: Nutrients, temperature (psychrophiles $\left(<25^{\circ} \mathrm{C}\right)$, mesophiles $\left(25\right.$ to $45^{\circ} \mathrm{C}$ ), thermophiles $\left(45\right.$ to $65^{\circ} \mathrm{C}$ ) (Cuesta, Sanchez, Vicente, \& S. Villar, 2009); (Varnero, 2011). The $\mathrm{pH}$ value (neutral) (Rosas Roa, 2007), solids content (between 8 and $12 \%$ ) (Hilbert, 2010), retention time, inhibitors, agitation-mixing, carbon-nitrogen ratio, moisture content (López, 2011). 
In order to preserve the good condition of the system or any element that mixes with the biogas to treat it as fuel, certain processes must be carried out to avoid any damage. In some cases, the treatment to use it will be less rigorous, while in others the biogas conditioning process will be more rigorous before using it.

Hilbert (2010) says that biogas, when evacuated from the biodigester, encounters water vapor, making the use of a water trap immersed in the plumbing system necessary.

Elimination of $\mathrm{CO}_{2}$. In the case of basic applications of biogas, such as water heaters, removal of $\mathrm{CO}_{2}$ is not indispensable. If biogas is used in vehicles, it is necessary to remove $\mathrm{CO}_{2}$ because the calorific value is raised and left almost on a par with natural gas.

Elimination of $\mathrm{H}_{2} \mathrm{~S}$, one of the most used ways to eliminate $\mathrm{H}_{2} \mathrm{~S}$ is a filter containing iron hydroxide through which the biogas passes forming iron sulfide (Hilbert, 2010).

Ammonia Removal, ammonia forms at high $\mathrm{pH}$ values in liquid guano. Therefore, the formation of ammonia can be avoided by proper operation of the plant. The method to remove the ammonia should also be used within the procedures to purify the biogas. As an alternative, there is a solution, ammonia reacts with carbon dioxide during a biochemical reaction to produce ammonium bicarbonate, which contributes to the alkalinity of the system (Varnero, 2011).

Discontinuous Biodigesters or Batch, the frequency of loading is only once in full and its discharge or emptying is done when biogas production is finished. This type of digester is commonly used when the raw material is limited; It has a single hermetically sealed entrance (lid). The time or speed of reaction of the organic matter that takes place in the biodigester are directly proportional to the temperature, that is to say that it greatly influences the climate where it will be located.

Figure 1

Discontinuous biodigester



Source: (Doerr \& Lehmkuhl, 2012)

Doerr \& Lehmkuhl (2012) point out that the elaboration of a discontinuous batch digester depends on the requirements that need to be met; based on this, the size of the biodigester is considered. They are usually made with 200-liter metal barrels, which have threaded holes, one of them is large and serves for putting excretions (Doerr \& Lehmkuhl, 2010). 
The small hole can be used for the gas outlet, both holes are located in the upper part of the barrel. It also has a valve that allows the closure of the gas line that connects to a tank.

Construction of this biodigester does not require great technical knowledge, the materials are easy to acquire at a low cost, it is very useful when the organic material is limited and it is easy to transport among others.

Several of the disadvantages of this type of biodigesters are that the materials used are not biodegradable, they have little efficiency due to having large organic material to be processed, the amount of biogas is limited to the volume of the biodigester and to the initial material load, its time of retention is high, etc.

Biodigester Taiwanese type, it is also known as tubular and its position on the ground is horizontal (figure 2), in the same way the first load of organic material is done in large quantities and as the gas generation decreases, it is constantly filled with more organic material.

Figure 2

Taiwanese biodigester model

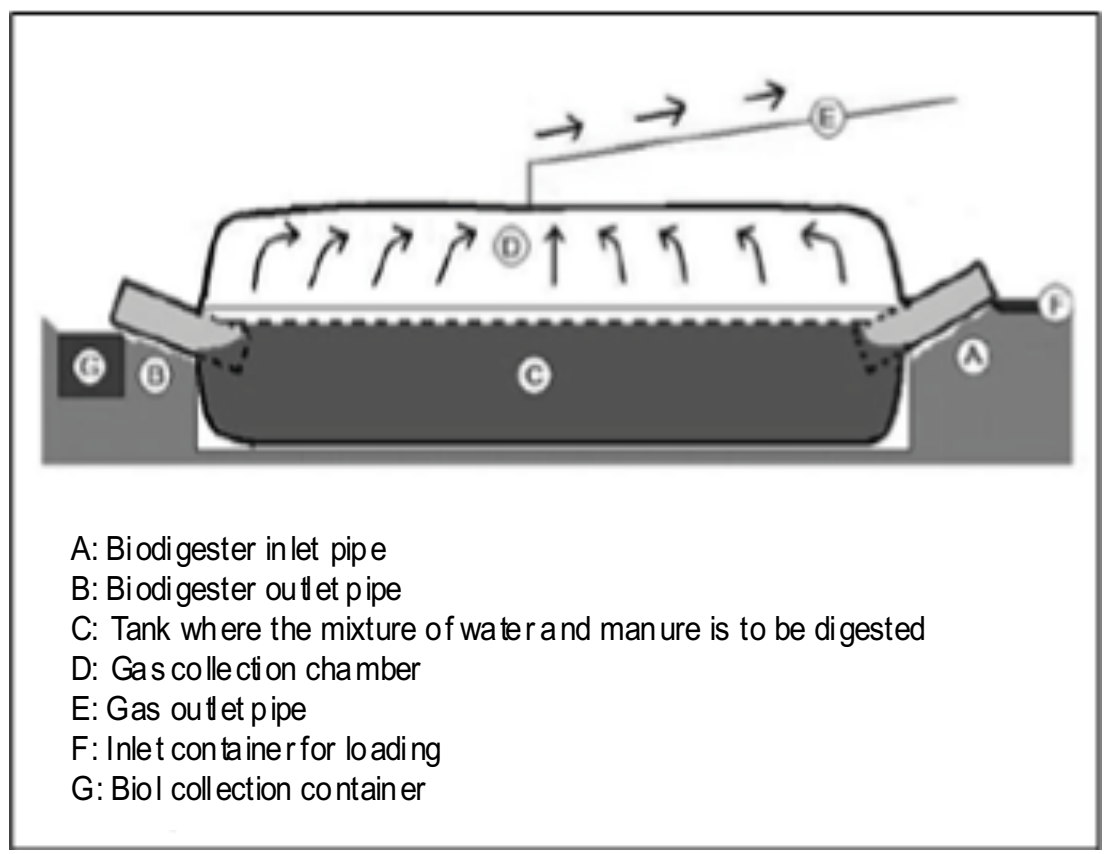

Source: (FAO, 2015)

It is basically used for the sanitation of sewage discharges, since its elongated conformation guarantees that the effluent, leaving the body of the digester, due to the flow and time of retention, is properly degraded (Rivera, 2010).

These digesters mostly have a small valve on the upper part that allows the gas to escape, and at the ends they have one for the entry of waste and the exit of the bio-fertilizer; the material is tubular polyethylene. They allow the handling of large amounts of waste per unit of volume, and they generate biogas with not very long periods of retention. Due to the ease of construction, the time required for its elaboration is short and the investment for construction is low.

The main disadvantages of this system are: the space required for its installation must be wide due to its elongated shape; it must be insulated from the ground because of its polyethylene construction material that is conducive to heat loss; its useful life depends on the climatic conditions to which it is subjected.

When building biodigesters, several factors have been taken into account, such as: location, land, construction materials, raw materials, among others. A determining factor for the construction of the biodigester is the 
amount of raw material (guinea pig excretions) that is available. Basically, the amount of biogas that will be generated at the end will depend on the quantity of raw material that can be entered into the biodigester. It was determined if it is viable to be used as a fuel, that is why this study helps determine if it is an alternative source, since an organic waste is supposed to be transformed into a resource.

\section{Method}

By means of an analysis carried out in a laboratory, its composition and characteristics could be studied. The results obtained give an idea of the behavior and viability of using the biogas of the two biodigesters.

\subsection{Location}

The parish of Calderon is located to the Northeast of the Metropolitan District of Quito, at a height of 2,659 meters above sea level, its soil is sandy and does not retain moisture. Which is favorable for the construction of a biodigester, since most of this sector are rural areas and there are spaces to build it and there is no effect on people.

\subsection{Climate}

Due to its geographic location, Calderon's climate is favorable for the functioning of a biodigester in relation to the temperature, due to the fact that during a great part of the year its weather is warm and there are no very strong rainfalls as generally occur in the South of Quito, in the mornings it is the temperate climate in an average of $16^{\circ} \mathrm{C} ; 21^{\circ} \mathrm{C}$ in summer.

\subsection{Process}

The construction of two types of biodigesters, a discontinuous type and a Taiwanese type, was carried out, taking into account certain parameters such as the location where they are built, since the climate makes certain priorities for their functioning. As in the case of the sleeve type, known by various names such as Taiwanese, tubular or sausage, the adequacy of the soil where the biodigester will be located will be of the utmost importance; which requires conditioning to provide firmness to the soil and isolate it as much as possible, so that there is no heat exchange between the soil and the body of the biodigester; it is necessary to use certain accessories to make connections, guaranteeing a hermetic seal.

A greenhouse was built so that the temperature inside it is higher than the ambient temperature, since the climate of Quito specifically in San Juan de Calderon is very changeable and can reach $12{ }^{\circ} \mathrm{C}$ in the early hours and at night. For this reason, it was decided to make a greenhouse of the following dimensions: $8 \mathrm{~m}$ long, $4 \mathrm{~m}$ wide and $2.5 \mathrm{~m}$ high, which housed the two biodigesters under acceptable temperature conditions.

\section{Sizing of Taiwanese biodigester}

Table 1

Dimensions of the Biodigester

\begin{tabular}{lr}
\hline Daily load of excretions & $20 \mathrm{~kg}$ \\
\hline Daily amount of liquid & $60 \mathrm{~L}$. \\
\hline Ratio of the excretions mixture and water & $1: 3$ \\
\hline Daily mixture (water, excretions) to enter & $80 \mathrm{~L}$. \\
\hline Retention time & 19 days \\
\hline Ambient temperature & $30^{\circ} \mathrm{C}$ \\
\hline Polyethylene gauge & Type 6 \\
\hline
\end{tabular}




\begin{tabular}{lr}
\hline Roll width & $1.50 \mathrm{~m}$ \\
\hline Length of the biodigester and the trench & $5.52 \mathrm{~m}$ \\
\hline Relationship between length and diameter of the biodigester & 5.75 \\
\hline Top width of the trench & $0.70 \mathrm{~m}$ \\
\hline Bottom width of the trench & $0.50 \mathrm{~m}$ \\
\hline Depth & $0.80 \mathrm{~m}$ \\
\hline Liquid volume & $1520 \mathrm{~L}$. \\
\hline Gaseous volume & $506.5 \mathrm{~L}$. \\
\hline Total volume & $2026.5 \mathrm{~L}$. \\
\hline
\end{tabular}

Source: authors own elaboration

It was decided to coat the inside of the trench to prevent any splinters or irregularities from damaging the biodigester.

Figure 3

Trench coating

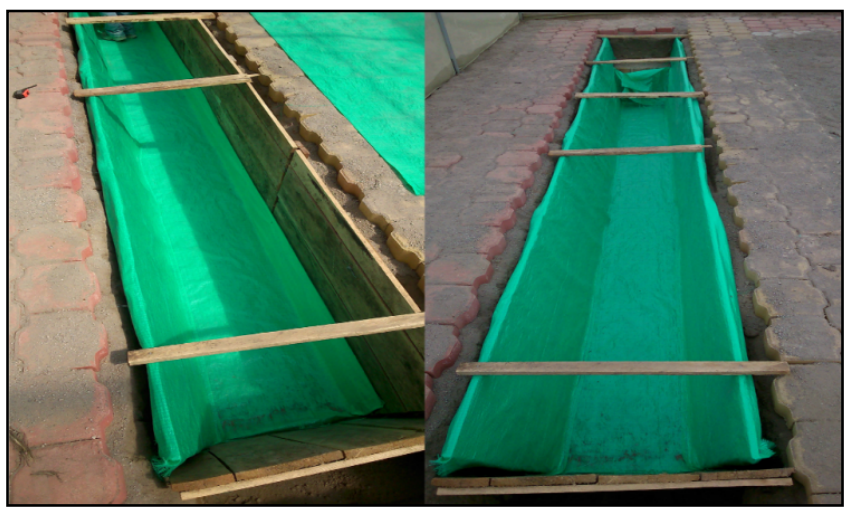

Source: : authors own elaboration

The largest number of elements other than excretions were removed, such as alfalfa, branches and balanced remains. After this a hexagonal mesh was used to separate smaller alien elements, in this way it was possible to have guinea pig excretions almost free of impurities, which is the most optimal to make the mixture.

In the case of water quality, the recommendations of Herrero (2008) and other documents that make reference to the water were taken into account, in which he mentions that it is preferable to use raw or rain water instead of drinking water.

\subsection{Discontinuous biodigester}

The tanks used were $1.2 \mathrm{~mm}$ thick low alloy carbon steel, with a capacity of 208 liters, they have two threaded holes with a diameter of 2 " and $3 / 4$ " at the top, respectively. They have corrugations that provide greater resistance to any force at which they may be submitted, having a height of $900 \mathrm{~mm}$ with a diameter of $585 \mathrm{~mm}$.

The volume entered into the tanks was a $75 \%$ of excretions-water mixture (156 L.) and a $25 \%$ destined for the gas chamber ( $52 \mathrm{~L}$.). Once the pertinent connections had been completed and the correct assembly of the system had been verified visually, the biodigesters were filled. The mixture planned to be introduced into each digester was 118 liters of water and $38 \mathrm{~kg}$ of guinea pig excretions, which was previously prepared in 210 -liter plastic tanks, for more convenience. 
Each tank was filled at a $75 \%$ of its total capacity, that is, 156 liters. After the loading of the biodigester, the tanks were sealed with their respective covers, previously Teflon and sealant were placed in the threading to avoid possible leaks, providing the appropriate adjustment.

\subsection{Generation of biogas}

Taiwanese biodigester (continuous). - The mixture inside the Taiwanese biodigester always remained optimal in each weekly sample that was made. The $\mathrm{pH}$ value did not present significant variations during the process, it remained close to the neutral value, which is 7 ; that is why there were no significant variations that would affect the process of digestion of the material.

The sample was taken from the outlet tube of the material, since it was much more accessible and avoided any action that would put the biodigester at risk.

Discontinuous biodigester. - At the end of the mixing of the excretions with the water and prior to putting it into this biodigester, the $\mathrm{pH}$ value of the mixture was measured; because once the mixture was inside the tanks, this test could not be carried out since the tanks would be kept hermetically sealed, this being a limitation to execute said measurement.

Elements for the conditioning of biogas

$\mathrm{H}_{2} \mathrm{~S}$ filter. - This element prevented the sulfuric acid from corroding any metallic element that could be part of the biogas tests. A simple filter was built in both the assembly and the handling part.

Water separator filter. - A water decanter is used to separate the presence of water in the biogas line.

\section{Results and discussion}

\subsection{Taiwanese biodigester}

This analysis was done to monitor the evolution of the Taiwanese biodigester and is divided into weeks for better understanding. Here we describe the variations of both pressure and temperature during the generation of biogas.

Figure 4

Formation of biogas by the Taiwanese system

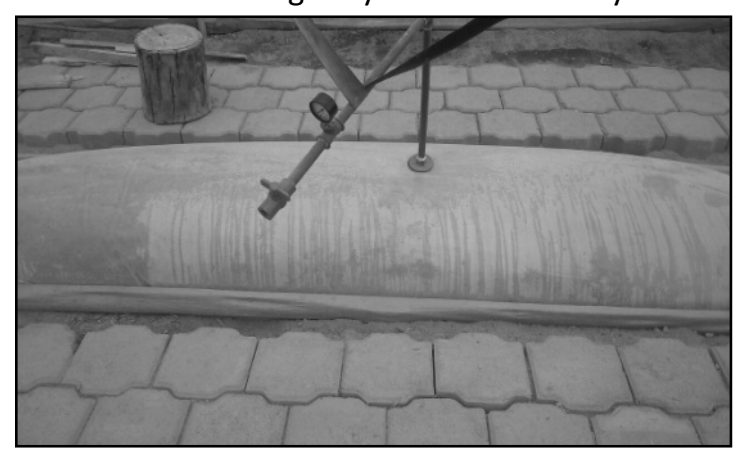

Source: authors own elaboration

First week. - The gas chamber showed no greater variation, as did not the temperature inside the greenhouse during the week. In the morning it was $18^{\circ} \mathrm{C}$, while in the afternoon it was $20^{\circ} \mathrm{C}$, having at noon an average temperature of $35^{\circ} \mathrm{C}$ in most of those days inside the greenhouse. 
The control with respect to the acidity of the material that was entered was constant, the $\mathrm{pH}$ value remained at 7 throughout the week.

Second week. - An increase in the gas chamber was noticeable, but it was not an elevated pressure because the pressure gauge showed values lower than $1 \mathrm{PSI}$. The temperature was constant at noon $\left(35^{\circ} \mathrm{C}\right)$ inside the greenhouse. With regard to acidity, the $\mathrm{pH}$ paper samples revealed a value of 7 .

Third week. - The weather this week was very favorable because there were very hot days, which is why in most of them the temperature was higher than $40{ }^{\circ} \mathrm{C}$ inside the greenhouse. This factor was decisive for the chamber to increase the amount of generated gas, at the end of this week the pressure was raised to 1 PSI. The acidity inspection of the mixture continued with a value of 7 on the $\mathrm{pH}$ scale.

Fourth week. - The weather tonic was similar to that of the first two weeks, with a temperature of $35{ }^{\circ} \mathrm{C}$ inside or a little higher some days. With this factor, the pressure in the gas chamber increased to $2 \mathrm{PSI}$, which was very good for the generation of biogas.

\subsection{Discontinuous biodigester}

The parameters were controlled in different days on the biodigester (figure 4), some of them remained without considerable variations, such as the temperature and the $\mathrm{pH}$ value.

Figure 5

Formation of biogas by the discontinuous system

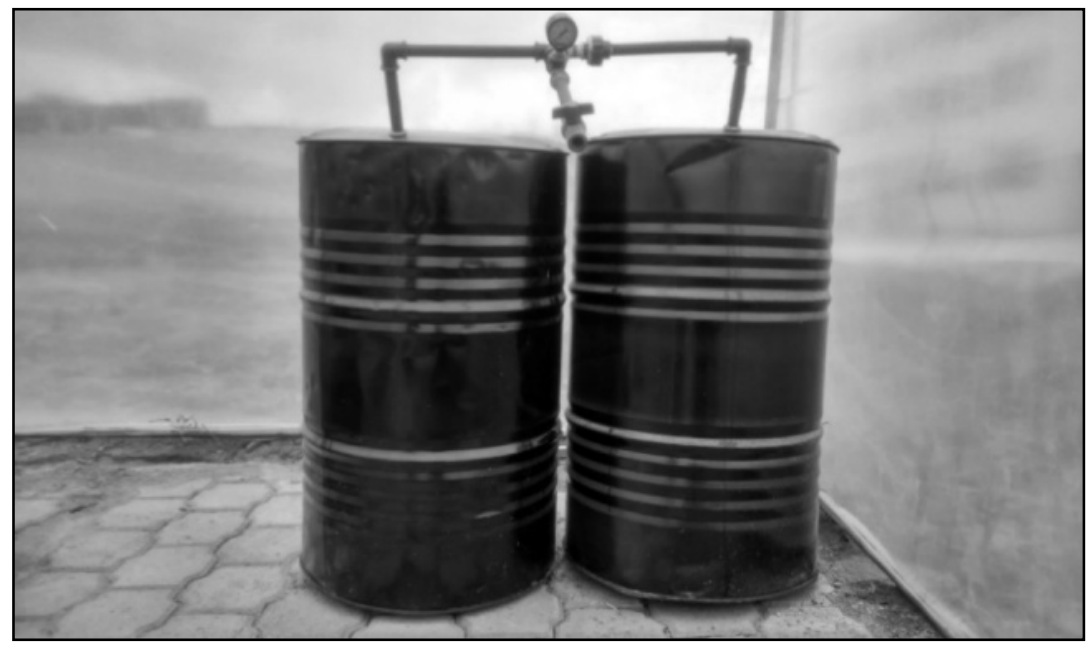

Source: authors own elaboration

First week. - The week after loading the biodigester, variations in the indicator boom were observed on the manometer, which marked a pressure of 2 psi. According to the information studied, it was known that during the first week pressure would be generated inside the tanks, which was only steam that should be released later.

Second week. - After the second week there was a pressure rise that had reached 5 PSI, it was decided to open the plastic passage valve and evacuate this water vapor contained inside the tanks. The pressure of 0 PSI was adequate to start the process of generating of the biogas inside the tanks.

Third week. - Every week the pressure increased between 2 and 3 PSI, reestablishing in a relatively short time, thanks to the high temperature inside the greenhouse; the maximum value that was generated was 10 PSI. The upper part of the tank was deformed due to the pressure it was bearing, also in the lower part the same alteration existed, but in a lesser proportion. 
That week there were temperatures that exceeded $40{ }^{\circ} \mathrm{C}$, inside, this situation was very beneficial for the development of biogas inside the tanks, but by increasing the temperature the retention time was reduced and the pressure was increasing quickly.

Fourth week. - That week the pressure reached the mark of 8 psi, considering that it should be maintained to avoid any event.

\subsection{Analysis of biogas}

The search to carry out this analysis led to the "Chemical Engineering Department" of the "National Polytechnic School", specifically to the "Instrumental Analysis Laboratory" that had the appropriate equipment.

The biogas was subjected to a gas chromatographic analysis, which showed the following values:

- Concentration in weight and moles of $\mathrm{CO}_{2}$, methane, nitrogen and water

- Determination of relative density

- Determination of molecular weight

- Determination of the caloric power

\section{Result of the biogas analysis (discontinuous biodigester)}

The report that was released by the Instrumental Analysis Laboratory, gave very interesting figures regarding the biogas. The table of the results obtained is shown below, the reference standard used was ASTM D 1945-03 (2010).

Table 2

Results of the biogas analysis

(discontinuous biodigester)

\begin{tabular}{|c|c|c|c|}
\hline \multicolumn{4}{|c|}{ Results obtained } \\
\hline Working conditions & \multicolumn{3}{|c|}{$\begin{array}{c}\text { Temperature }\left({ }^{\circ}\right) \\
20\end{array}$} \\
\hline \multirow{5}{*}{$\begin{array}{l}\text { RESULTS } \\
\text { (Composition) }\end{array}$} & Component & \% weight & $\%$ moles \\
\hline & Nitrogen & 7.12 & 7.14 \\
\hline & Methane & 28.60 & 50.10 \\
\hline & Carbon dioxide & 62.43 & 39.87 \\
\hline & Water & 1.85 & 2.89 \\
\hline \multirow{4}{*}{$\begin{array}{l}\text { RESULTS } \\
\text { (Properties) }\end{array}$} & Relative density $\left(20^{\circ} \mathrm{C}, 0.72 \mathrm{~atm}\right)$ & \multicolumn{2}{|r|}{0.98} \\
\hline & Average molecular weight $[\mathrm{g} / \mathrm{mol}]$ & \multicolumn{2}{|r|}{28.10} \\
\hline & Calorific power over $25^{\circ} \mathrm{C}$ [Btu / lb] & \multicolumn{2}{|r|}{11954.44} \\
\hline & Calorific power less than $25^{\circ} \mathrm{C}$ [Btu / lb] & \multicolumn{2}{|r|}{10772.57} \\
\hline
\end{tabular}

Source: Instrumental Analysis Laboratory; National Polytechnic School

The excretions-water mixture that entered the interior of the biodigestor was successful in its mission to generate biogas, as confirmed by the laboratory analysis report. The presence of $50.10 \%$ of methane gas moles $(\mathrm{CH} 4)$ in the sample is optimal, taking into account that the percentage of $\mathrm{CH} 4$ within a biogas is between $50 \%$ and 70 \% (López, 2011). A Bunsen burner should be used to achieve the ignition of biogas with this amount of methane, this element allows us to regulate the amount of oxygen necessary for a good combustion.

Now referring to Fernandez (2009), with respect to the percentages of $\mathrm{CO}_{2}$ within a biogas, ranging from $35 \%$ to $45 \%$. In the analysis it is observed that the second quantity with the greatest existence is carbon dioxide moles with $39.87 \%$, this value agrees with the parameter expressed at the beginning of the paragraph. 
Perhaps the somewhat excessive proportion that the analysis shows is the one of nitrogen moles (7\%), in comparison with the data of Rosas (2007) indicating a margin of $0.5-3.0 \%$ of $\mathrm{N}_{2}$. The percentage of water moles is $2.89 \%$, being the least amount.

In the case of properties, biogas has a molecular weight of $28.10 \mathrm{~g} / \mathrm{mol}$. The relative density is 0.98 at the temperature of $20^{\circ} \mathrm{C}$, under the pressure of $0.72 \mathrm{~atm}$.

The most relevant of this report is the calorific value above $25{ }^{\circ} \mathrm{C}$ which is $11954.44 \mathrm{Btu} / \mathrm{lb}(6370.08 \mathrm{Kcal} / \mathrm{m} 3)$, while the calorific value below $25^{\circ} \mathrm{C}$ is $10772.57 \mathrm{Btu} / \mathrm{lb}(5740.30 \mathrm{Kcal} / \mathrm{m} 3)$.

These values are close to those of (Rosas, 2007, p 273) in which he mentions that the calorific value of biogas is $5335 \mathrm{Kcal} / \mathrm{m} 3$.

Thus, in general terms, the biogas analyzed complies with the majority of the parameters of several studied texts and is therefore suitable as a combustible agent.

Taking the sample for analysis (Taiwanese biodigester)

The conditions that this second sample had to fulfill were equal to those of the discontinuous biodigester. The biogas previously passed through the $\mathrm{H}_{2} \mathrm{~S}$ and water filters. The pressure at which the biogas came out was not very high compared to the discontinuous system, but it was enough to be able to take a sample.

\subsection{Result of biogas analysis (Taiwanese biodigester)}

This second report, which was issued by the Instrumental Analysis Laboratory, has the same format as the previous one. The table of the results obtained is shown below, the reference standard used was ASTM D 194503 (2010).

Table 3

Results of the biogas analysis (Taiwanese biodigester)

\begin{tabular}{|c|c|c|c|}
\hline \multicolumn{4}{|c|}{ Results obtained } \\
\hline \multirow[t]{3}{*}{ Working conditions } & \multirow{2}{*}{\multicolumn{3}{|c|}{$\begin{array}{c}\text { Temperature }\left({ }^{\circ}\right) \\
20 \\
\end{array}$}} \\
\hline & & & \\
\hline & Component & \% weight & $\%$ moles \\
\hline \multirow{6}{*}{$\begin{array}{l}\text { RESULTS } \\
\text { (Composition) }\end{array}$} & Nitrogen & 2.55 & 3.72 \\
\hline & Methane & 2.36 & 6.00 \\
\hline & Carbon dioxide & 93.24 & 86.35 \\
\hline & Water & 1.54 & 3.48 \\
\hline & Relative density $\left(20^{\circ} \mathrm{C}, 0.72 \mathrm{~atm}\right)$ & & 1.41 \\
\hline & Average molecular weight $[\mathrm{g} / \mathrm{mol}]$ & & 40.63 \\
\hline \multirow{2}{*}{$\begin{array}{l}\text { RESULTS } \\
\text { (Properties) }\end{array}$} & Calorific power over $25^{\circ} \mathrm{C}$ [Btu/lb] & & 1431.16 \\
\hline & Calorific power less than $25^{\circ} \mathrm{C}[\mathrm{Btu} / \mathrm{lb}]$ & & 1289.67 \\
\hline
\end{tabular}

Source: Instrumental Analysis Laboratory; National Polytechnic School

The presence of $6.00 \%$ moles of methane gas $\left(\mathrm{CH}_{4}\right)$ in the sample is not optimal, taking into account (Lopez, 2011) that the percentage of $\mathrm{CH}_{4}$ inside a biodigester is between $50 \%$ to $70 \%$.

According to Fernandez $\left(2009\right.$, p.331), the percentages of $\mathrm{CO}_{2}$ inside a biogas range from $35 \%$ to $45 \%$. The analysis indicates that carbon dioxide is $86.35 \%$ Moles, this value is excessively high with the parameter mentioned at the beginning of this paragraph. 
The ratio of nitrogen moles is $3.72 \%$, surpassing the values indicated by Rosas (2007) with a margin of 0.5-3.0 \% of N2. The percentage of water moles is $3.48 \%$, being this one the least amount.

In the case of the properties, the biogas has a molecular weight of $40.63 \mathrm{~g} / \mathrm{mol}$. The relative density is 1.42 at the temperature of $20^{\circ} \mathrm{C}$, under the pressure of $0.72 \mathrm{~atm}$.

This report with respect to the calorific value above $25^{\circ} \mathrm{C}$ expresses that it is $1431.16 \mathrm{Btu} / \mathrm{lb}$, while the calorific value below $25{ }^{\circ} \mathrm{C}$ is $289.67 \mathrm{Btu} / \mathrm{lb}$. Compared to the calorific powers of biogas (discontinuous system), these values are relatively negligible.

These last values are very far from those expressed by Rosas (2007) who states that the calorific value of biogas is $5335 \mathrm{Kcal} / \mathrm{m}^{3}$. In general, the analyzed biogas from the Taiwanese biodigester does not comply with most of the parameters of several consulted texts and therefore is not suitable as a combustible agent.

Comparison of the results of Taiwanese and discontinuous biogas

Next, the biogas generated by the discontinuous system is compared with the biogas produced by the Taiwanese system, for a better understanding it was decided to contrast the aspects of composition and properties separately.

\subsection{Biogas discontinuous system vs Taiwanese system}

Graphic 1

Composition of the Biogas (discontinuous system vs Taiwanese system)

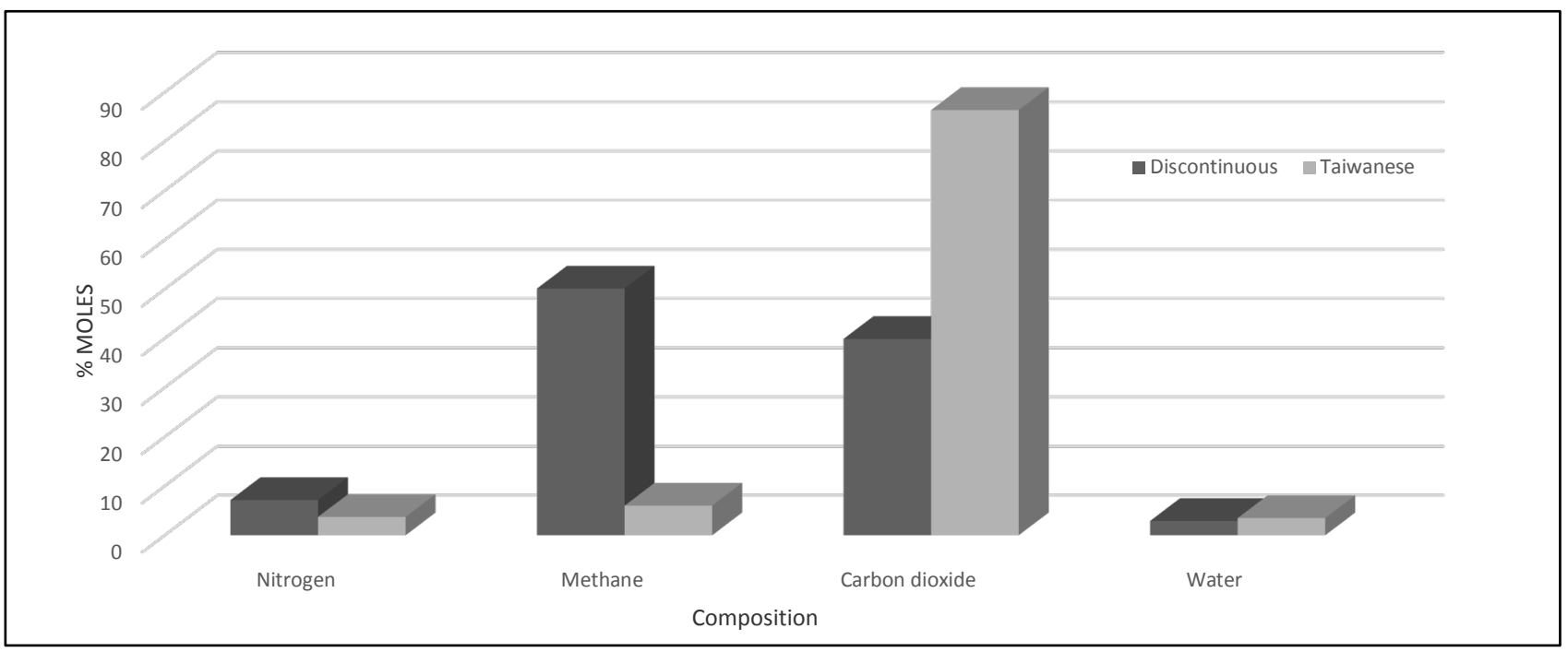

Source : authors own elaboration

As a first point, the composition of the biogas is observed between the two systems that were used. Clearly the figure shows that the product generated by the discontinuous system has a higher percentage of nitrogen, methane and water, all this compared to the Taiwanese system.

The biogas generated by the discontinuous biodigester has a very high percentage of methane $(50.10 \%)$, comparing to its Taiwanese counterpart. The only high amount in the case of the latter was the amount of carbon dioxide (86.35\%).

The following figure refers to certain properties, it is noted that the relative density of the biogas of the Taiwanese system is higher than the relative density of the biogas of the discontinuous system. The same trend is observed in the case of the molecular weight. 


\subsection{Biogas discontinuous system vs Taiwanese system}

Graphic 2

Properties of Biogas (discontinuous system vs Taiwanese)



Source: authors own elaboration

The superior and inferior calorific value of the discontinuous system are clearly high compared to the Taiwanese system, and that is why it was previously shown that it complies with the parameters of a biogas. As seen in graphic 2 , there is a very marked gap.

\subsection{Biogas discontinuous system vs Taiwanese system}

Graphic 3

Properties of Biogas (discontinuous system vs Taiwanese)

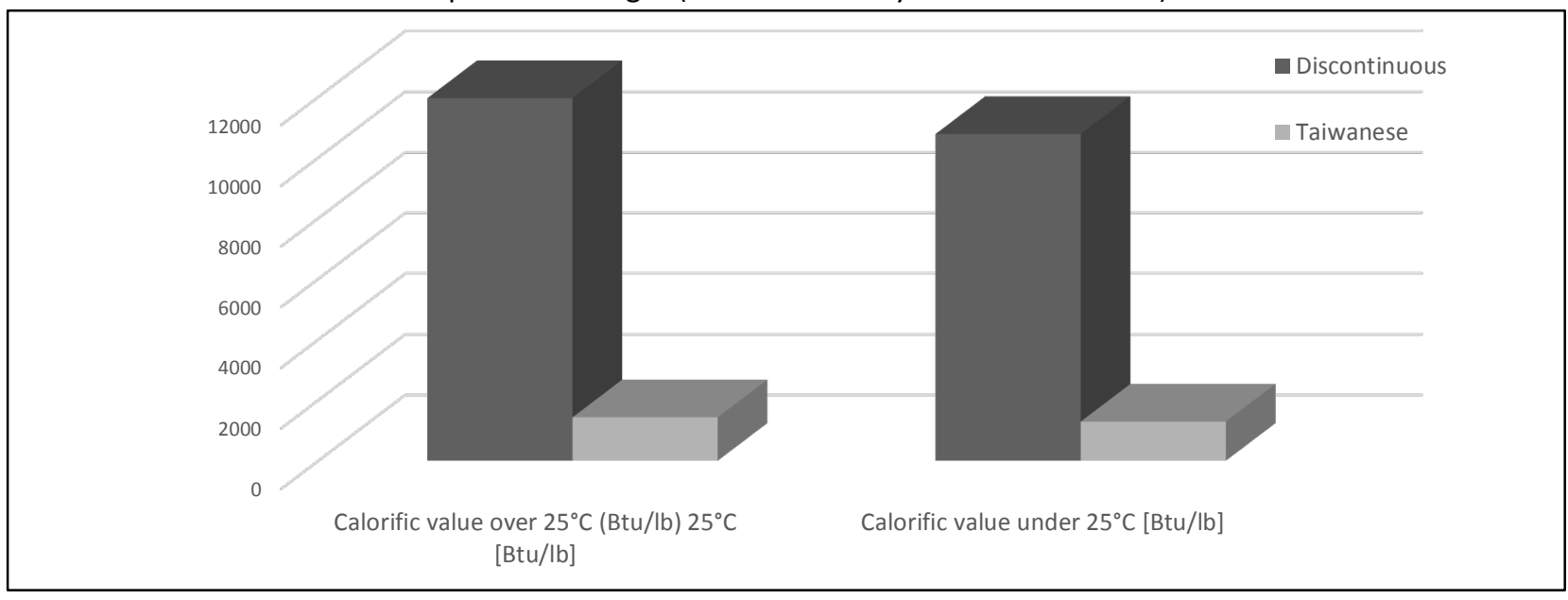

Source: authors own elaboration

Comparison of the calorific value of the biogas obtained (discontinuous) with different fuels.

The values of the generated biogas have been related to the information given to us by Rosas (2007). In this way, the process carried out prior to obtaining gas is more truthful. 


\section{Graphic 4}

Comparison of the calorific value of the biogas

obtained (discontinuous) with different fuels.

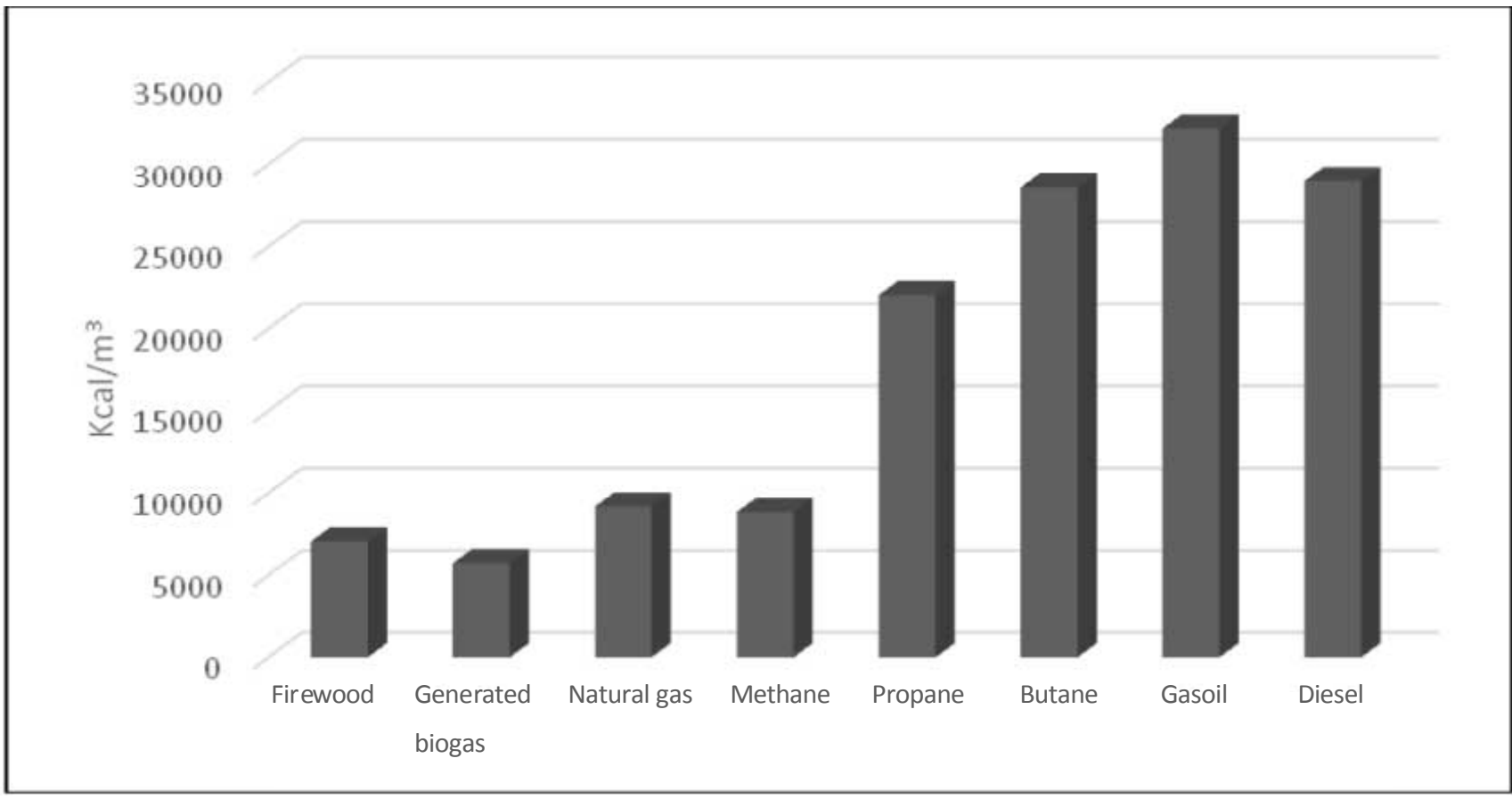

Source: authors own elaboration

As expected, the generated biogas (discontinuous system) is of lower calorific value compared to other fuels, but it can be very useful in different tasks entrusted, which often use non-renewable energy sources.

\section{Conclusions}

The results obtained are based on previous technical experiences and the biodigesters were conditioned to a greenhouse in order to achieve higher temperatures than those that the locations situated at heights above 2,500 meters above sea level usually have, and therefore avoid different climatic conditions inherent to that specific locality.

By means of the laboratory analysis performed on the biogas sample that was generated from guinea pig excretions in the discontinuous biodigester, it was possible to find out that in the composition there was a very good concentration of methane gas moles, specifically $50.10 \%$, which means that it can be used as an alternative energy source.

The analysis made to the Taiwanese biodigester generated the data that were not expected in the production of biogas, but it can be used to carry out corrective actions in order to improve the biodigestion process at heights above 2000 masl. The generated amount was $6 \%$ of methane gas, a low amount comparing to the discontinuous system, but which encourages to continue the studies in order to obtain a bigger amount of this gas.

The biogas generated by the discontinuous system can be used in several applications and could replace the use of firewood or natural gas taking into account the calorific value obtained. The height at which the results were obtained must be taken into account, because due to weather conditions, the values could affect certain processes. 


\section{References}

Cuesta, J., Sanchez, F., Vicente, G., \& S. Villar. (2009). Situación actual de la producción del biogás y de su aprovechamiento. Madrid: Fundación Madrid para el Conocimiento.

Doerr, B., \& Lehmkuhl, N. (2010). Metane Digesters. Florida: Echo.

FAO. (2015). Biogas Technology: A Training Manual For Extension. Kathmandu: C.M.S.

Fernández Salgado, J. (2009). Tecnología de las Energias Renovables. Madrid: Mundi-Prensa.

González, J. (2009). Energías renovables. Barcelona: Reverté.

Herrero, J. M. (2008). Biodigestores familiares: Guía de diseño y manual de instalación. La Paz: GTZ.

Hilbert, J. A. (2010). Manual para la producción de Biogas. Buenos Aires: INTA.

López, G. (2011). Producción de biogás a partir de RSU. Bogotá: Universidad Distrital Francisco José de Caldas.

Rivera, M. (2010). Producción de fertilizantes orgánicos y biogás mediante biodigestión anaeróbica de lodos activos. La Serena, Chile: Tesis.

Rosas Roa, A. (2007). Agricultura orgánica práctica. Bogotá: Medios Impresos.

Varnero, M. T. (2011). Manual de Biogás. (M. /. Proyecto CHI/00/G32, Ed.) Santiago de Chile.

Esta obra está bajo una Licencia Creative Commons

Attribución-NoCommercial 4.0 International

(cc) EYY-NC 